\title{
Kwaliteit van opleidingen
}

Bij visitaties door de VSNU en opiniepeilingen, zoals de indrukken die door de gids van Elsevier worden gewekt, wordt de kwaliteit van de opleidingen in de gezondheidszorg in het algemeen als goed beoordeeld. Als docenten mogen we daar best trots op zijn. Door een aantal mensen wordt er ook al jarenlang met veel inzet gewerkt aan de kwaliteit van opleidingen. Het is wel van belang om te beseffen dat visitaties en opiniepeilingen relatieve metingen zijn. Het gaat steeds om vergelijkingen, dus je kunt ook ten onrechte gerust of tevreden zijn. Eigenlijk zouden we in absolute zin iets over de kwaliteit moeten weten. Helaas ontbreekt een gouden standaard, dus dat gaat niet zo gemakkelijk.

Over voorwaarden voor kwaliteit valt wel iets te zeggen. Een belangrijke voorwaarde voor goed onderwijs zijn goede docenten. Er wordt al heel lang gezegd dat er een onderwijscarrière moet komen. Ik hoor ook wel eens in landelijke bijeenkomsten dat er op allerlei plekken al mogelijkheden zouden zijn. In het echt wordt het onderwijs ten onrechte - nog steeds niet even belangrijk gevonden als patiëntenzorg en onderzoek. Wij zorgen dan ook nog steeds niet zo goed voor onze docenten. Dat bleek ook een paar jaar geleden op het Gezond Onderwijs Congres. Er werd een enquête over stress afgenomen. Wij - docenten en bezoekers van het congres - bleken veel stress en een hoge werkdruk te hebben in vergelijking met andere groepen in de samenleving.

Een andere voorwaarde voor kwaliteit is het budget van de opleiding. De aantallen medische studenten zijn de laatste jaren fors toegenomen. De overheid heeft daar 'geoormerkt' geld voor vrijgemaakt. Kennelijk heeft de gemeenschap dus geld over voor kwalitatief goede opleidingen. Als je gaat uitzoeken waar dat geld blijft, blijkt dat een groot gedeelte aan de universitaire strijkstok blijft hangen, althans niet wordt ingezet voor onderwijs. Hetzelfde geldt al heel lang voor de rijksbijdrage, die aan de academische ziekenhuizen wordt overgemaakt. De genoemde 'lagere' overheden hollen dus een besluit van de gemeenschap uit en besteden het geld op andere wijze. Dit fenomeen, dat al lang bekend is, 'suddert' rustig door, hoewel het erg frusterend is voor mensen die zich inzetten voor goed onderwijs, dat er nu voor de werkvloer maar beperkte middelen overblijven. Zo is bekend dat de invulling van co-assistentschappen al lang niet optimaal is. Hoe merkwaardig uit het oogpunt van kwaliteit is het dan dat er een aantal jaren geleden besloten is om de affiliatievergoedingen te verlagen.

Een belangrijke bron van informatie over onderwijskwaliteit is onderzoek van onderwijs. We weten helaas niet allemaal dat er onderzoek van onderwijs is en dat er resultaten zijn die gebruikt kunnen worden om de kwaliteit te verbeteren. Faculteiten investeren heel weinig in onderzoek van onderwijs en heel veel in ander onderzoek. Voor de kwaliteit van onderwijs is dit niet hoopgevend.

Samenvattend, kan ik volgen dat de kwaliteit in relatieve zin wel aardig lijkt. In absolute zin valt er echter nog heel wat te verbeteren.

Albert Scherpbier 